\title{
STYLISTIC ANALYSIS OF THE POEM "DURING WIND AND RAIN" BY THOMAS HARDY
}

\author{
Aulia Putri \\ (English Language Study Program, University of Riau Kepulauan, Indonesia) \\ auliaputri1983@yahoo.com
}

\begin{abstract}
This study is aimed to analyze Thomas Hardy's poem "During Wind and Rain" from the view of stylistic analysis. It is seen through the aspects of graphological levels, phonological levels, morphological levels, and lexico-syntactical level. Graphological levels deal with punctuations. While, phonological levels discuss about rhyme, alliteration, consonance, assonance. Moreover, morphological levels are about affixes and compounding. At last, lexico-syntactical levels talk about semantic levels. This analysis is useful in revealing the meanings of the poem.
\end{abstract}

Keywords : Poetry Analysis, Stylistic Analysis, Thomas Hardy

\section{INTRODUCTION}

\section{Stylistics Analysis}

David Crystal sees stylistics as a branch of linguistics which "studies certain aspects of language variation" (as cited in Khan, et al., 2015). Furthermore, Turner (as cited in Ahmed and Irshad, 2016) explains stylistics as a part of linguistics which focuses on the use of language in literature While, Leech (as cited in Abdurrahman, 2016) describes stylistics in literature as the study of the writer's style; for instance the use of language in literature to scrutinize the general features of language as a means of literary expressions. In doing stylistic analysis, foregrounding is needed. Leech and Short (as cited in Arikan, 2015) describe foregrounding as an 'artistically motivated deviation'. Widdowson and Carter mention that stylistic is a bridge between linguistics and literature (Arikan, 2015). From the above understandings, it can be concluded that when analyzing a poem as a literary work, it can be seen from two aspects; literature and linguistics. Thus, this scrutinizing process can be done through stylistic analysis. 


\section{Level s of Stylistics Analysis}

\section{Graphology}

Crystal and Davy (as cited in Ahmed and Irshad, 2015) mentions that graphology is the analogous study of language writing system. Elements include in graphology are punctuation and paragraphing. Kinds of punctuation are periods [.], ellipsis marks [...], commas [,], semi colons [;], colons [:], question marks [?], exclamation points [!], quotation marks ["], parentheses [( )], apostrophes ['], hyphens [-], dashes [--]. (Straus, 2008)

2. Phonology

Lodge (as cited in Ahmed and Irshad, 2015) explains that phonology is the study of linguistic systems, particularly the way in which sound represents the differences of meaning in a language. In poems, it can be found in rhyme, alliteration, consonance, assonance.

3. Morphology

Ackema and Neeleman (2007, p.3 ) conclude the definition of Morphology from some experts saying that Morphology is a generative system that classify grammatical word structure. The elements of morphology are: affixes and compounding.

\section{Lexico-Syntax}

It comes from two words; "lexis' means vocabulary and "syntax" means sentence structure. It analyzes word pattern on semantic level which includes: Metaphor, Simile, Personification, Irony, Tone, Anaphora, Hyperbole, Imagery, Symbol, Allusion, Deictic words, Collocation, Metonymy, Synonym, Compounding, Antithesis, Linking words, Natural words, Old English words. The lexical elements are Noun, Pronoun, Verb, Adjective, Adverb.

\section{The Poet and the Poem}

\section{a. Poet's Biography}


Thomas Hardy is recognized as a unique English writer both as novelist and a poet. He is also brilliant in his combination of a selfconsciously 'modern' cast of thought with a passionate, actually paradoxical, concern with the personal, local, and national past. He was born in 1840 in the English countryside. He lived and created his masterpieces until he was 88 years old. (Millgate, 2004, p.7)

\section{b. During Wind and Rain}

"During Wind and Rain" was written in 1917 by Thomas Hardy, five years after the death of his beloved wife Emma Hardy. It is structured like a song shown in the form of repeated refrain at the beginning and end of each stanza. It tells about life and death, and the passing of time. He distinguishes the joy of life and the inevitability of death.

\section{METHODOLOGY}

The study implements the stylistic analysis of a poem "During Wind and Rain" by Thomas Hardy with the aim of looking at the poet's choice of language. Graham (as cited inVerdonk, 1993, p.3) states that the regular levels of linguistic analysis are phonology/graphology, grammar, lexis, and semantics). Moreover Leech and Short (2007, p. 95) distinguish three levels of organization in language namely the level of semantics (meaning), the levels of syntax (also called 'lexigrammar') and phonology. These two levels represent what is often referred to as the 'double articulation' of linguistic form: phonology as the 'sound pattern' of the language (phonemes, stress, rhythm, intonation), and syntax as the more abstract grammatical and lexical form of language. In line with the previous understand dings, this study deals with graphological levels, phonological levels, morphological levels and lexico-syntactical levels. Graphological levels deal with punctuations, while in phonological levels discuss about rhyme, alliteration, consonance, assonance. 
Moreover, morphological levels are about affixes and compounding. Last but not least, lexico-syntactical levels talk about semantic levels.

\section{FINDINGS}

1. Graphological Levels

Table 1. Graphological Levels

\begin{tabular}{llcc}
\hline & \multicolumn{1}{c}{ Type } & Total & Percentages \\
\hline a) & Exclamation Points (!) & 3 & $6.38 \%$ \\
b) & Semi colons (;) & 7 & $14.89 \%$ \\
c) & Periods (.) & 3 & $6.38 \%$ \\
d) & Commas (,) & 21 & $44.68 \%$ \\
e) & Hyphens (-) & 2 & $4.26 \%$ \\
f) & Dashes (--) & 7 & $14.89 \%$ \\
g) & Ellipsis Marks (...) & 4 & $8.51 \%$ \\
\hline \multicolumn{2}{r}{ Total } & $\mathbf{4 7}$ & $\mathbf{1 0 0 \%}$ \\
\hline
\end{tabular}

2. Phonological Levels

a. Rhyme Scheme

The poem consists of four stanzas with seven lines each. The pattern of the rhyme is ABCBCDA.

b. Sound Devices

Table 2. Sound Devices

\begin{tabular}{llcc}
\hline & \multicolumn{1}{c}{ Type } & Total & Percentages \\
\hline a. & Alliteration & 13 & $28.26 \%$ \\
b. & Assonance & 23 & $50 \%$ \\
c. & Consonance & 10 & $21.74 \%$ \\
\hline \multicolumn{1}{r}{ Total } & $\mathbf{4 6}$ & $\mathbf{1 0 0 \%}$ \\
\hline
\end{tabular}

3. Morphological levels

Table 3. Morphological Levels

\begin{tabular}{rlcc}
\hline & \multicolumn{1}{c}{ Type } & Total & Percentages \\
\hline d. & Affixes & 25 & $62.5 \%$ \\
e. & Compounding & 15 & $37.5 \%$ \\
\hline \multicolumn{2}{r}{ Total } & $\mathbf{4 0}$ & $\mathbf{1 0 0 \%}$ \\
\hline
\end{tabular}

4. Lexico-Syntactic Levels

a. Semantic Levels

Table 4. Semantic Levels 


\begin{tabular}{ccc}
\hline Type & Total & Percentages \\
\hline Anaphore & 1 & \\
Metaphor & 4 & $\mathbf{1 0 0 \%}$ \\
\hline Total & $\mathbf{2 9}$ &
\end{tabular}

b. Lexical Levels

The lexical levels in the poem are:

Table 5. Lexical Levels

\begin{tabular}{|c|c|c|}
\hline Type & Total & Percentages \\
\hline Noun and Pronoun & 37 & $56.92 \%$ \\
\hline Verb & 14 & $21.54 \%$ \\
\hline Adjective & 11 & $16.92 \%$ \\
\hline Adverb & 3 & $4.62 \%$ \\
\hline Total & 65 & $100 \%$ \\
\hline
\end{tabular}

\section{DISCUSSION}

1. Graphological Level

There are four stanzas with seven lines each. Several punctuations are used in them:

a. Exclamation Points (!)

Line 6: Ah, no; the years $\mathrm{O} !^{1}$

Line 7: How the sick leaves reel down in throngs!

Line 20: Ah, no; the years $\mathrm{O} !^{3}$

b. Semi colons (;)

Line 4: And one to play; ${ }_{2}^{1}$

Line 6: $\mathrm{Ah}, \mathrm{no}_{2}^{2}$ the years $\mathrm{O}$ !

Line 11: And the garden gay: ${ }_{2}^{3}$

Line 13: $\mathrm{Ah}, \mathrm{no}_{2}^{4}$ the years, the years,

Line 20: $\mathrm{Ah}, \mathrm{no}_{2}^{-5}$ the years $\mathrm{O}$ !

Line 27:Ah, no $_{2}^{6}$ the years, the years ${ }_{2}^{7}$

C. Periods (.)

Line 14: See, the white storm-birds wing across. ${ }_{-}^{1}$

Line 21: And the rotten rose is ript from the wall. ${ }_{-}^{2}$

Line 28: Down their carved names the rain-drop ploughs. ${ }_{.}^{3}$

d. Commas (,)

Line 2: He, ${ }^{1}$ she, ${ }^{2}$ all of them-yea, ${ }^{3}$

Line 3: Treble and tenor and bass, ${ }^{4}$ 
Line 6: $\mathrm{Ah},{ }^{5}$ no; the years $\mathrm{O}$ !

Line 9: Elders and juniors - aye, ${ }^{6}$

Line 13: $\mathrm{Ah},{ }^{7}$ no; the years, ${ }^{8}$ the years, ${ }^{9}$

Line 14: See, ${ }^{10}$ the white storm-birds wing across.

Line 16: Men and maidens-yea, ${ }^{11}$

Line 17: Under the summer tree, ${ }^{12}$

Line 18: With a glimpse of the bay, ${ }^{13}$

Line 20: $\mathrm{Ah},{ }^{14}$ no; the years $\mathrm{O}$ !

Line 22: They change to a high new house, ${ }^{15}$

Line 23: He, ${ }^{16}$ she,${ }^{17}$ all of them-aye, ${ }^{18}$

Line 25: On the lawn all day, ${ }^{19}$

Line 27: Ah, ${ }^{20}$ no; the years, ${ }^{21}$ the years;

e. Hyphens (-)

Line 14: See, the white storm- ${ }^{1}$ birds wing across.

Line 28: Down their carved names the rain- ${ }^{2}$ drop ploughs.

f. Dashes (--)

Line 1: They sing their dearest songs -1

Line 2: He, she, all of them $-^{2}$ yea,

Line 8: They clear the creeping moss-3

Line 9: Elders and juniors - ${ }^{4}$ aye,

Line 15: They are blithely breakfasting all -5

Line 16: Men and maidens - ${ }^{6}$ yea,

Line 23: He, she, all of them-7 aye,

g. Ellipsis Marks (....)

Hardy uses ellipses to state moments that are unfinished. It refers to

death as it is known as sudden and inevitable. The ellipses in the poem

are:

Line 5: With the candles mooning each face....

Line 12: And they build a shady seat. ... ${ }^{2}$

Line 19: While pet fowl come to the knee. ...

Line 26: And brightest things that are theirs. ...

2. Phonological Level

The verses are rhymed ABCBCDA.

a. In the first stanza, rhyme A comes from the words "songs" and

"throngs", while rhyme B is from the words "yea" and "play".

Then, rhyme $\mathrm{C}$ is formed from the words "bass" and "face". 
b. Next, in the second stanza, rhyme A is from "moss" and "across". After that, rhyme B is taken from the words "aye" and "gay". Besides, rhyme C is from "neat" and "seat".

c. In the third stanza, it has "all" and "wall" as rhyme A. Next, the words "yea" and "bay" are shaped rhyme B. Meanwhile, the words "tree" and "knee" shapes the rhyme C.

d. In the last stanza, rhyme A is shaped from the words "house" and "ploughs". Rhyme B is taken from the words "aye" and "day". At last, the words "chairs" and "theirs" form rhyme C.

e. Table 6. Sound Devices

\begin{tabular}{|c|c|c|}
\hline Alliteration & Assonance & Consonance \\
\hline They, their & They, their & Candles, face, \\
\hline Sing, song & He, she & Elders $\underline{\text {, juniors }}$ \\
\hline Treble, tenor & Tréble, tenor & And, build \\
\hline Clear, $\underline{\text { creeping }}$ & Leaves, reel & Storm-birds $\underline{\text { across }}$ \\
\hline Garden, gay & Clear, creeping & Under, summer \\
\hline Shady, seat & Build, seat & While, fowl \\
\hline White, wing & See, wing & Clock $\underline{s}$, carpets $\underline{s}$, chair $\underline{s}$ \\
\hline Blithely, & $\overrightarrow{\text { Men, yea }}$ & On, lawn \\
\hline breakfasting & Under, summer & Things, theirs \\
\hline Men, maidens & With, glimpse & Names, ploughs \\
\hline Rotten, rose, rip & Rotten, rose, from, wall & \\
\hline High, house & They, change, & \\
\hline Clocks, carpets, & Their, names, rain & \\
\hline chairs & Down, ploughs & \\
\hline Things, that, & Songs, throngs & \\
\hline theirs & Yea, play & \\
\hline & Bass, face & \\
\hline & Moss, across & \\
\hline & Neat, seat & \\
\hline & Yea, bay & \\
\hline & Tree, knee & \\
\hline & House, ploughs & \\
\hline & Chairs, theirs & \\
\hline
\end{tabular}

3. Morphological Level

a. Affixes

The poem consists of suffixes only; there is no pre-fixes found. It consists of free morphemes and bound morphemes. 


$\begin{array}{ll}\text { Dearest } & =\text { dear }+ \text { est } \\ \text { Songs } & =\text { song }+\mathrm{s} \\ \text { Candles } & =\text { candle }+\mathrm{s} \\ \text { Years } & =\text { year }+\mathrm{s} \\ \text { Leaves } & =\text { leaf }+\mathrm{s} \\ \text { Throngs } & =\text { throng }+\mathrm{s} \\ \text { Creeping } & =\text { creep }+ \text { ing } \\ \text { Elders } & =\text { old }+\mathrm{er}+\mathrm{s} \\ \text { Junior } & =\text { junior }+\mathrm{s} \\ \text { Making } & =\text { make }+ \text { ing } \\ \text { Pathways } & =\text { path }+\mathrm{way}+\mathrm{s} \\ \text { Shady } & =\text { shade }+\mathrm{y} \\ \text { Birds } & =\text { bird }+\mathrm{s} \\ \text { Blithely } & =\text { blithe }+ \text { ly } \\ \text { Breakfasting } & =\text { break }+ \text { fast }+ \text { ing } \\ \text { Maidens } & =\text { maid }+ \text { en }+\mathrm{s} \\ \text { Ript } & =\text { rip }+ \text { ed } \\ \text { Clocks } & =\text { clock }+\mathrm{s} \\ \text { Carpets } & =\text { carpet }=\mathrm{s} \\ \text { Chairs } & =\text { chair }+\mathrm{s} \\ \text { Brightest } & =\text { bright }+\mathrm{est} \\ \text { Things } & =\text { thing }+\mathrm{s} \\ \text { Carved } & =\text { carve }+\mathrm{ed} \\ \text { Names } & =\text { name }+\mathrm{s} \\ \text { Ploughs } & \text { Compounding } \\ & \end{array}$

The Compounding used by Hardy in the poem are:

Dearest song, pathways, white storm-birds, blithely breakfasting, , sick leaves, reel down, creeping moss, garden gay, shady seat, summer tree, 
rotten rose, high new house, brightest things, carved names, rain-drop ploughs

4. Lexico-Syntactical Levels

a. Lexical Levels

Table 7. Lexical Levels

\begin{tabular}{lllc}
\hline \multicolumn{1}{c}{ Noun and Pronoun } & \multicolumn{1}{c}{ Verb } & \multicolumn{1}{c}{ Adjective } & Adverb \\
\hline They & Sing & Dearest & Down \\
Their dearest songs & Play & Sick & Blithely \\
He & Mooning & Creeping & Under \\
She & Reel & Neat & \\
All of them & Clear & Shady & \\
Treble & Making & White & \\
Tenor & Build & Rotten & \\
Bass & See & High & \\
One & Wing & New & \\
The candles & Breakfasting & Brightest & \\
Each face & Come & Carved & \\
The years & Ript & & \\
The sick leaves & Change & & \\
Throngs & Plough & \\
The creeping moss & & \\
Elders & & \\
Juniors & & \\
The pathways & & \\
The garden gay & & \\
A shady seat & & \\
The white storm-birds & & & \\
Men & & \\
Maidens & & \\
The summer tree & & \\
A glimpse of the bay & & \\
Pet & & \\
The knee & & \\
The rotten rose & & \\
The wall & & \\
A high new house & & \\
Clocks & & \\
Carpets & & \\
Chairs & & \\
The lawn & & \\
Brightest things & & \\
Their carved-names & & \\
\hline
\end{tabular}


b. Semantic Levels

1) Metaphor

Line 5: With the candles mooning each face....

Line 28: Down their carved names the rain-drop ploughs

2) Personification

Line 7: How the sick leaves reel down in throngs!

3) Tone

Cheerfulness is shown in line 1: "They sing their dearest songs_-"and also in the first line of each stanza.

Grief is illustrated in line 8: "How the sick leaves reel down in throngs!" and in the last line of each stanza as well.

4) Anaphora

There are repetitions of word year, it can be seen below:

Line 2: He, she, all of them-yea,

Line 23: He, she, all of them-yea,

Line 13: Ah, no; the years O!

Line 27: Ah, no; the years $\mathrm{O}$ !

5) Hyperbole

It is described in words like ript, ploughs, throngs.

6) Imagery

Almost all parts of the poem are built from imagery. In the first stanza, it captures the winter season; the family does things that make them happy by singing and playing music. Then, the second stanza shows spring season; they start gardening and cleaning up after the winter. Next, the third stanza depicts summer season with a family picture. The final stanza still portrays summer but the family unit move in to a new residence.

7) Symbols

Song: In the poem, songs symbolize happiness.

Sick leaves: These words indicate someone is dying or close to death. Rotten rose: It is a symbolic word for loss.

A high new house: This noun phrase represents prosperity.

8) Deictic words

Person deixis: they, their, he, she, them, one, theirs 
Spatial deixis: come

9) Collocation

Line 10: Making the pathways neat.

Line 12: And they build a shady seat....

10) Antithesis

Line 2: $\underline{\mathrm{He}}$, she, all of them-yea,

Line 9: Elders and juniors - aye,

Line 16: Men and maidens - yea,

Line 23: He, she, all of them-yea,

11) Linking Words

The poem only has linking word "and" as shown below:

Line 3: Treble and tenor and bass,

Line 4: And one to play;

Line 9: Elders and juniors - aye,

Line 11: And the garden gay;

Line 12: And they build a shady seat. . .

Line 16: Men and maidens-yea,

Line 21: And the rotten rose is ript from the wall.

Line 24: Clocks and carpets and chairs

Line 26: And brightest things that are theirs... .

12) Natural words

The poem includes natural worlds such as:

Leaves, moss, garden, tree, bay, rose

13) Old English words

The old English words are: Aye, Yea.

\section{CONCLUSION}

From the use of punctuation, Hardy wants the reader to feel the emotions that he has toward the poem. He wants the readers to feel the pace in what he enjoys in the beauty of life and how in a sudden it is taken away by death. Besides, the rhymes also strengthen the tone of the poem as it talks about joyfulness and loss. It can be seen from the use of various sound devices as well. Moreover, Hardy uses several compounding and figurative language to enhance the feelings of the poem. 


\title{
REFERENCES
}

Abdurrahman, Israa' Burhanuddin. (2016). A Stylistic Analysis of Complexity in William Faulkner's "A Rose for Emily". Advances in Language and Literary Studies Vol. 7 No. 4; August 2016 Doi:10.7575/aiac.alls.v.7n.4p.220 retrieved from http://dx.doi.org/10.7575/aiac.alls.v.7n.4p.220

Ackema, Peter and Neeleman, Ad. 2007. Beyond Morphology: Interface Conditions on Word Formation. New York: Oxford University Press Inc.

Ahmed, Mumtaz and Irshad, Ayesha. (2015). Stylistic Analysis of Robert Browning's Poem. Advances in Language and Literary Studies No. 4; August 2015 Doi:10.7575/aiac.alls.v.6n.4p.11 retrieved from http://dx.doi.org/10.7575/aiac.alls.v.6n.4p.11

Arikan, Arda. (2015). Doing stylistic analysis: some fundamental techniques. $15^{\text {th }}$ International Stylistics Symposium retrieved from http://aves.akdeniz.edu.tr/YayinGoster.aspx? ID=2744\&NO=119

Hall, Donald. (1992). To Read a Poem ( $2^{\text {nd }}$ ed). Florida: Holt, Rinehart and Winston, Inc.

Khan, et.al. (2015). Stylistic Analysis of the Short Story 'The Last Word' by Dr. A. R. Tabassum Advances in Language and Literary Studies Vol. 6 No. 3; June 2015 Doi:10.7575/aiac.alls.v.6n.3p.10 retrieved from http://dx.doi.org/10.7575/aiac.alls.v.6n.3p.10

Leech, Geoffrey and Short, Mick. (2007). Style in Fiction: A Linguistic Introduction to English Fictional Prose $\left(2^{\text {nd }} E d\right)$. Edinburgh: Pearson Education Limited

Millgater, Michael. 2004. Thomas Hardy: A Biography Revisited. New York: Oxford University Press, Inc.

Straus, Jane. (2008). The Blue Book of Grammar and Punctuation (10 ${ }^{\text {th }}$ ed). San Francisco: A Wiley Imprint

Verdonk, Peter. (1993). Twentieth-Century Poetry: From Text to Context. London: Routledge.

\section{APPENDIX}

\author{
During Wind and Rain \\ (Thomas Hardy-1917)
}


They sing their dearest songs-

$\mathrm{He}$, she, all of them-yea,

Treble and tenor and bass,

And one to play;

With the candles mooning each face. ...

$\mathrm{Ah}$, no; the years $\mathrm{O}$ !

How the sick leaves reel down in throngs!

They clear the creeping moss-

Elders and juniors - aye,

Making the pathways neat

And the garden gay;

And they build a shady seat. . .

Ah, no; the years, the years,

See, the white storm-birds wing across.

They are blithely breakfasting all-

Men and maidens - yea,

Under the summer tree,

With a glimpse of the bay,

While pet fowl come to the knee. ...

$\mathrm{Ah}$, no; the years $\mathrm{O}$ !

And the rotten rose is ri pt from the wall.

They change to a high new house,

$\mathrm{He}$, she, all of them - aye,

Clocks and carpets and chairs

On the lawn all day,

And brightest things that are theirs. ...

Ah, no; the years, the years;

Down their carved names the rain-drop ploughs.

(Hall, 1992) 